\title{
PENGENALAN PLAT KENDARAAN BERMOTOR DENGAN MENGGUNAKAN METODE TEMPLATE MATCHING DAN DEEP BELIEF NETWORK
}

\author{
Michael $^{1}$, Frenky Tanoto $^{2}$, Eric Wibowo ${ }^{3}$, Frenky Lutan ${ }^{4}$, Abdi Dharma $^{5}$ \\ 1,2,3,4,5 Program Studi Teknik Informatika, Universitas Prima Indonesia \\ Email: abdidharma@unprimdn.ac.id
}

\begin{abstract}
ABSTRAK
Plat nomor kendaraan bermotor itu unik dan hanya dimiliki oleh satu kendaraan per seri plat kendaraan, untuk memudahkan polisi, terutama polisi lalu lintas, untuk melacak pelanggar lalu lintas melalui plat nomor kendaraan. Algoritma Deep Belief Network bekerja dengan memproses dataset melalui 3 tahapan, dimana layer pertama dilatih, hasil layer pertama kemudian dilatih lagi, dan hasil perhitungan layer ke dua dijadikan hitungan layer ke tiga, hasil mean pada perhitugan layer ke tiga menjadi hasil dari pembelajaran Deep Belief Network, kemudian dengan Template Matching algoritma Deep Belief Network dibantu untuk pengenalan plat kendaraan. Dalam penelitian yang dilakukan dengan menggunakan algoritma DBN dengan metode Template Matching berhasil mengenali plat kendaraan dengan persentase keberhasilan sebesar $80 \%$ dari 20 kali percobaan. Percobaan yang dilakukan mengikut sertakan plat yang tidak jelas dilihat. Kegagalan yang terjadi dalam pengenalan umumnya dikarenakan pencahayaan yang kurang atau berlebih pada plat kendaraan.
\end{abstract}

\section{Kata Kunci: deep belief network, plat kendaraan, template matching, pengenalan}

\begin{abstract}
The license plate of the vehicle is unique and is only owned by one vehicle per vehicle plate series, to make it easier for the police, especially the traffic police, to track traffic violators through the vehicle number plate. The Deep Belief Network algorithm works by processing the dataset through 3 stages, where the first layer is trained, the results of the first layer are then re-trained, and the results of the second layer calculation are made into the third layer count, the mean results on the calculation of the third layer become the result of learning Deep Belief Network then with the Template Matching algorithm, Deep Belief Network is assisted with the introduction of vehicle plates. In a study conducted using the DBN algorithm with the Template Matching method succeeded in recognizing a vehicle plate with a success percentage of $80 \%$ from 20 trials. The experiments carried out included plates that were not clearly seen. Failures that occur in the trials are generally due to under- or over-lighting on the vehicle plate.
\end{abstract}

Keyword: deep belief network, vehicle plat, template matching, python, identification

Author Korespondensi (Abdi Dharma)

Email : abdidharma@unprimdn.ac.id

\section{PENDAHULUAN}

Plat nomor kendaraan unik dan hanya dimiliki oleh satu kendaraan per satu seri plat kendaraan, ini memudahkan polisi, terutama polisi lalu lintas, untuk melacak pelanggar lalu lintas. Pengenalan pelat kendaraan dapat dilakukan secara manual dengan mencocokkan pelat kendaraan yang ada dengan data konvensional yang disimpan dalam database. Namun, metode konvensional cukup memakan waktu dan banyak akal. Untuk itu, diperlukan pemrosesan gambar di mana gambar yang diambil dapat langsung diproses untuk mendapatkan data berdasarkan pelat kendaraan.

Sebelumnya dalam penelitian tentang pengenalan kendaraan bermotor ada beberapa metode yang digunakan, seperti metode Backpropagation dalam penelitian berjudul "Sistem Pengenalan Nomor Plat Kendaraan Berdasarkan Foto Digital dengan Metode Invarian dan Jaringan Syaraf Tiruan menggunakan Metode Backpropagation" di mana persentase pengakuan keberhasilan adalah 95\% [1]. Metode Learning Vector Quantization yan kemudian digunakan dalam penelitian berjudul "Identifikasi Plat Kendaraan Berbasis Mobile dengan Metode Learning Vector Quantization" keberhasilan pengenalan mencapai $95,32 \%$ [2]

Tetapi dalam kedua studi plat kendaraan tidak terdeteksi secara otomatis, tetapi harus dipotong secara manual oleh pengguna. 
Sehingga kurang efektif, selain itu penelitian yang dilakukan hanya menggunakan plat kendaraan berwarna hitam. Deep Belief Network merupakan pengembangan dari deep learning. Algoritma Deep Belief Network mencakup algoritma terawasi dan tidak terawasi yang dapat memanfaatkan data berlabel atau tidak berlabel.

Pada penelitian dengan metode Deep Belief Network sebelumnya yang berjudul "Research on the Classification Ability of Deep Belief Networks on Small and Medium Datasets". Deep Belief Networks memiliki perfoma terburuk dalam melakukan pengklasifikasian data set kecil, namun dalam melakukan pengklasifikasin data gambar DBN memiliki performa yang lebih baik dibandingkan algoritma pengklasifikasian lainnya [3].

Kemudian pada penelitian dengan judul "Sentimen Analisis Tweet Berbahasa Indonesia dengan Deep Belief Network" algoritma Deep Belief Network digunakan untuk melakukan klasifikasi terhadap tweet dimana pada penelitian klasifikasi yang dilakukan oleh Deep Belief Network lebih baik dari pada Support Vector Machine, dan Naïve Bayes [15].

Template Matching adalah salah satu metode pemrosesan gambar yang menentukan tepi gambar dan dibandingkan dengan templat gambar yang ada dalam dataset yang telah dipelajari.

Sebelumnya pada penelitian dengan metode Template Matching yang berjudul "Implementasi Metode Template Matching untuk Media Pembelajaran dengan Pengenalan Karakter Huruf Alphabet" dimana dengan menggunakan metode template matching algoritma template matching berhasil mengenali karakter alphabet dengan persentasi keberhasilan mencapai $80 \%$ dimana semakin tebal garis tulisan alphabet, lebih tinggi persentasi metode template matching untuk mengenali tulisan alphabet [4].

\section{METODOLOGI}

Prosedur kerja yang dilakukan, akan mengikuti metode penelitian waterfall. Di mana hal pertama yang akan dilakukan adalah melakukan analisis sistem. Di mana hasil analisis sistem seperti bagan alur berikut.

Jenis penelitian yang digunakan adalah penelitian kuantitatif dimana penelitian dilakukan dengan mengembangkan model matematika, teori atau hipotesis. Untuk metode penelitian, metode yang digunakan adalah waterfall. Di mana pesanannya adalah sebagai berikut:

1. Analisis Kebutuhan

Pada tahapan ini penulis melakukan analisa terhadap kegiatan yang dilakukan oleh pihak kepolisian maupun ticketing pada parkir kendaraan. Dimana pada Analisa ini terdapat beberapa kemudahan yang dapat dilakukan apabila plat kendaraan dapat dikenali secara langsung oleh sistem. Misalnya pada pihak kepolisian, dapat digunakan untuk e-tilang. Kemudian pada ticketing parkir dapat digunakan untuk mengenali plat kendaraan sebelum melakukan parker kendaraan.

2. Desain Sistem

3. Koding

4. Menguji Program

5. Kesimpulan dan Saran

Setelah mendapatkan deskripsi sistem yang akan dibangun pada penelitian yang dilakukan, pengumpulan data populasi dilakukan untuk penelitian di mana populasi penelitian adalah gambar berwarna 2D. Sampel penelitian ini terdiri dari 1000 gambar yang terdiri dari 250 gambar plat kendaraan hitam, 250 gambar plat kendaraan kuning, 250 gambar plat kendaraan putih, dan 250 gambar plat kendaraan merah. Sampel memiliki ukuran gambar yang gratis dalam format .jpg.

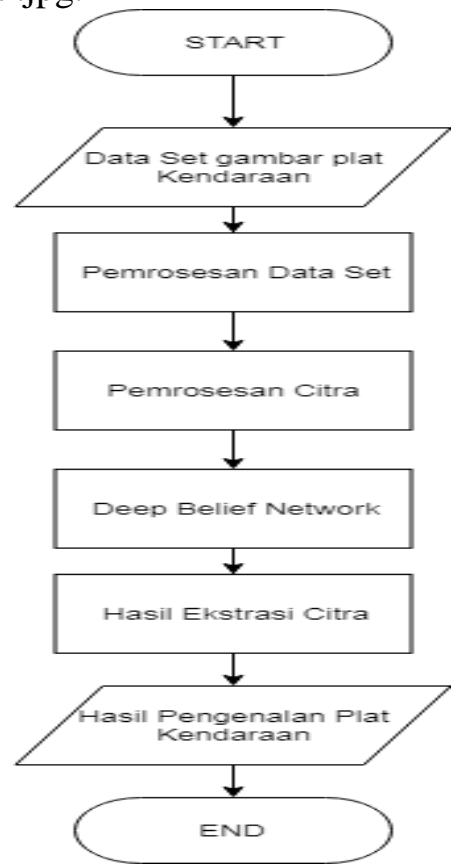

Gambar 1. Flowchart Penelitian

Setelah kumpulan data dikumpulkan, program akan mengkodekan dan kemudian 
dataset akan dipelajari. Setelah selesai, aplikasi akan dicoba dan kesimpulan dan saran akan diambil dari hasil percobaan.

Dalam penelitian ini gambar plat kendaraan berwarna hitam, putih, kuning, dan merah adalah variabel dalam penelitian ini. Contoh berikut adalah variabel untuk pengenalan plat nomor kendaraan.

Tabel 1. Contoh Variabel

\begin{tabular}{|c|c|}
\hline Image & Variabel \\
\hline $\bar{B}$ BK 1909 JA & Black Vehicle Plate \\
\hline$B 2833 \mathrm{XKX}$ & White Vehicle Plate \\
\hline $3 k-1296$ & Red Vehicle Plate \\
\hline $8: 186$ & $\begin{array}{c}\text { Yellow Vehicle } \\
\text { Plate }\end{array}$ \\
\hline
\end{tabular}

Dataset yang terdiri dari 1000 gambar dikumpulkan dari pemotretan langsung, sedangkan sampel untuk kendaraan di luar kota akan diambil dari gambar yang diperoleh dari situs web seperti gambar google.

Pengolahan citra merupakan istilah umum untuk berbagai teknik memanipulasi dan memodifikasi citra dengan berbagai cara [5].

Deep Belief Networks adalah representasi grafis yang pada dasarnya generatif, yaitu untuk menghasilkan semua nilai yang mungkin yang dapat dihasilkan untuk kasus yang dihadapi. Ini adalah kombinasi dari probabilitas dan statistik dengan pembelajaran mesin dan jaringan saraf

1. Lapisan pertama dilatih dari data pelatihan dengan rakus, sementara semua lapisan lainnya dibekukan. Kami memperoleh probabilitas aktivasi individu untuk lapisan tersembunyi pertama. Semua unit tersembunyi dari lapisan tersembunyi pertama diperbarui secara paralel. Ini disebut fase positif.

2. Kemudian unit rekonstruksi dilihat menggunakan fase negatif yang merupakan teknik serupa dengan fase positif.

Langkah terakhir dalam pembelajaran layer dengan metode Greedy adalah memperbarui semua bobot terkait. L adalah tingkat pembelajaran yang kita kalikan dengan perbedaan antara nilai-nilai fase positif dan negatif dan menambah nilai awal bobot.

Aplikasi pengenalan pelat kendaraan ini dapat dimodelkan menggunakan diagram use case seperti gambar 2 berikut.

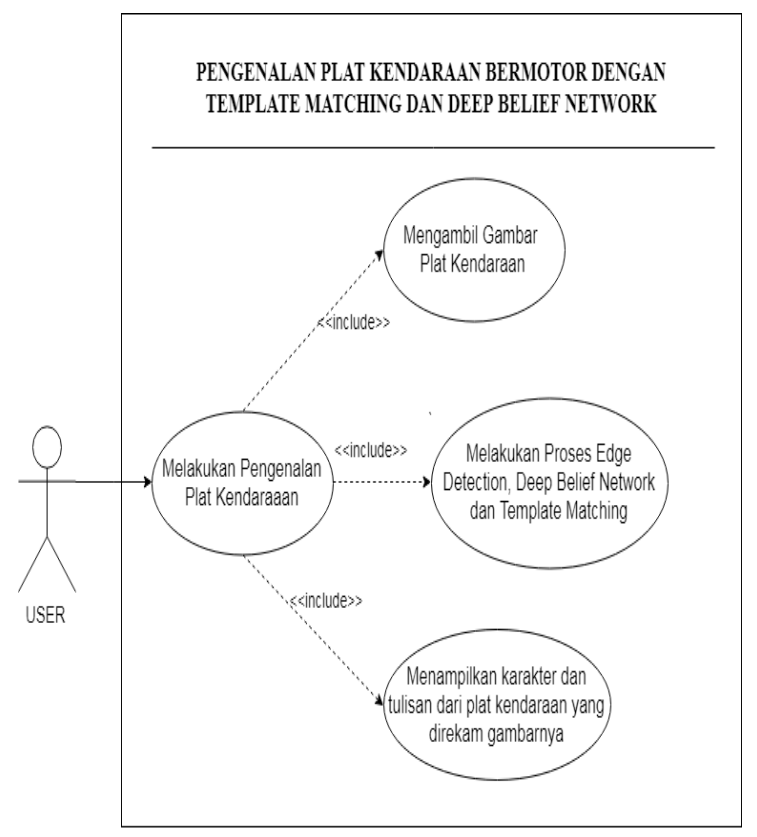

Gambar 2 Usecase diagram

Langkah-langkah dalam menghasilkan hasil ekstrasi informasi dari gambar atau citra adalah :

1. Melakukan penginputan citra dimana dapat dilakukan dengan menggunakan camera dari laptop.

2. Kemudian citra hasil akan disimpan dan diesktrasi. Untuk jumlah piksel hitam berurutan kurang dari atau lebih dari batasan threshold yang ditentukan kemudian piksel tersebut akan diubah menjadi warna putih [6]. Untuk kemudian akan segmentasi pada gambar. Segmentasi pada dasarnya adalah proses memisahkan area pengamatan (region) pada tiap karakter yang dideteksi [7].

3. Kemudian hasil segmentasi akan diproses, untuk melakukan pengenalan angka dan huruf pada plat kendaraan.

Proses kerja dari metode Template Matching dan Deep Belief Network dalam mengenali karakter pada plat kendaraan dapat digambarkan sebagai berikut: 


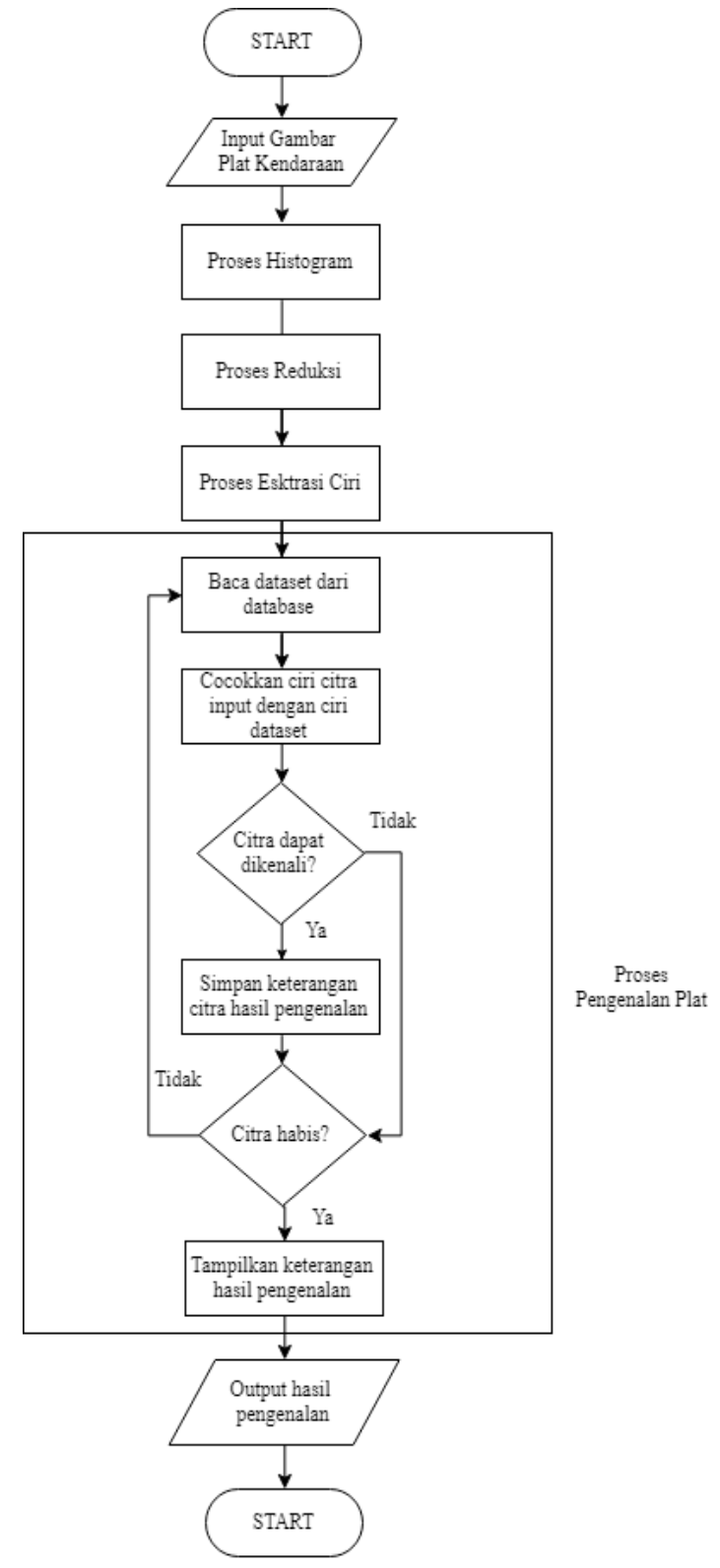

Gambar 3 Skema FlowChart Metode Template Matching dan DBN

Informasi yang terdapat dalam knowledge base disimpan dalam bentuk file text . Pada tulisan ini dibuatkan data pelatihan yang terdiri dari image/citra yang berisi 36 karaketer (A-Z dan 0-9) sebanyak 22 kolom. Perlu diketahui bahwa proses pelatihan dibuat terpisah dengan proses pengenalan. Proses pelatihan dilakukan di luar sistem pengenalan. Sesudah dilakukan proses pelatihan, data hasil pelatihan disimpan sebagai basis data untuk pengenal pola.

Di mana setiap penambahan informasi pada knowledge base, maka informasi tersebut akan ditambahkan pada akhir file tersebut.

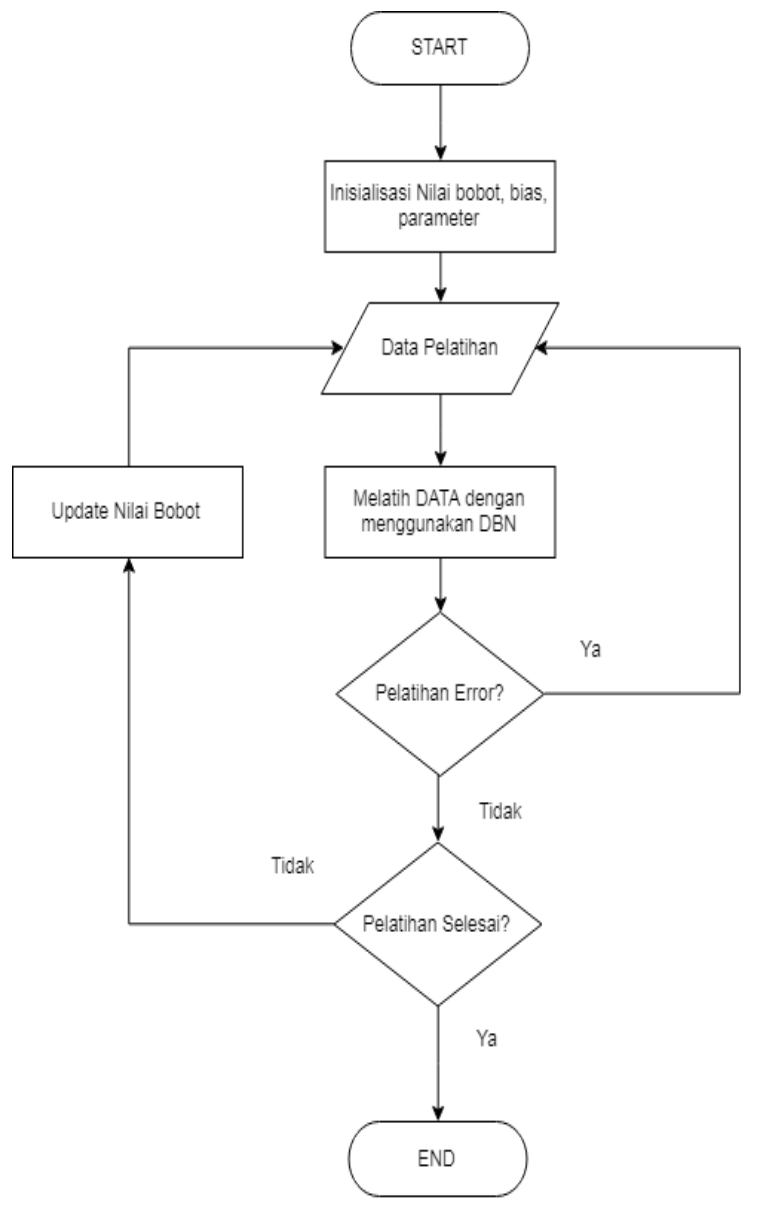

Gambar 4 Rancangan Flowchart data Pelatihan

DBN adalah kumpulan dari RBM, kecuali RBM lapisan pertama yang berisi koneksi tidak langsung.

Perancangan deep belief network dibagi menjadi 2 tahapan yaitu tahap pembelajaran dan tahap klasifikasi [15]. Sekali stack dari RBM yang ditrain, itu dapat digunakan untuk menginiliasisasi sebuah multilayer neural network untuk klasifikasi [8].

Pada penelitian ini konfigurasi DBN yang digunakan adalah dengan menggunakan 3 layer dalam melakukan pembelajarannya dimana setiap layer memiliki modal.

Proses Deep Belief Network Setelah RBM pertama selesai dilatih, kemudian pola aktivitas pada RBM pertama yang merupakan lapisan tersembunyi akan diambil, kemudian akan digunakan sebagai data pada proses pelatihan RBM kedua. Proses ini kemudian juga dapat berarti membentuk tumpukan (stack) RBM [9]. Proses Deep Belief Network dapat dirincikan sebagai berikut: 
1. Lapisan pertama dilatih dari data pelatihan dengan rakus, sementara semua lapisan lainnya dibekukan. Kami memperoleh probabilitas aktivasi individu untuk lapisan tersembunyi pertama. Semua unit tersembunyi dari lapisan tersembunyi pertama diperbarui secara paralel. Ini disebut sebagai fase positif.

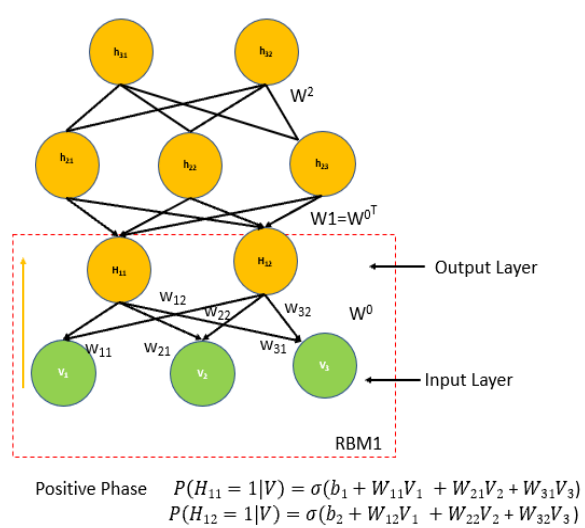

Gambar 5 Contoh Proses DBN

2. Kemudian dilakukan rekonstruksi unit yang terlihat menggunakan fase negatif yang merupakan teknik serupa seperti fase positif.

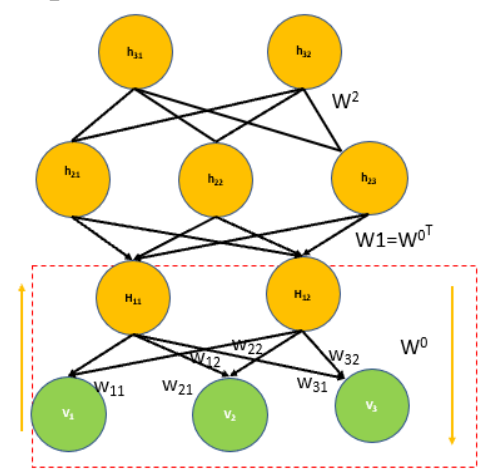

$\begin{array}{ll}\text { Negative Phase } & P\left(V_{1}=1 \mid H_{1}\right)=\sigma\left(a_{1}+W_{11} H_{11}+W_{12} H_{12}\right) \\ & P\left(V_{2}=1 \mid H_{1}\right)=\sigma\left(a_{2}+W_{21} H_{11}+W_{22} H_{12}\right)\end{array}$ $P\left(V_{2}=1 \mid H_{1}\right)=\sigma\left(a_{2}+W_{21} H_{11}+W_{22} H_{12}\right)$
$P\left(V_{3}=1 \mid H_{1}\right)=\sigma\left(a_{3}+W_{31} H_{11}+W_{32} H_{12}\right)$

Gambar 6 Contoh Proses DBN

Langkah terakhir dalam pembelajaran layer dengan metode Greedy adalah memperbarui semua bobot terkait. L adalah tingkat pembelajaran yang kita kalikan dengan perbedaan antara nilai fase positif dan negatif dan menambah nilai awal bobot.

Setiap gambar memiliki sebuah pola karakteristik masing-masing, adanya karakter atau pola suatu gambar dapat memanipulasi dan mengubah suatu gambar dengan menggunakan komputer. Hal tersebut terlihat dari penggunaan komputer yang mampu mengubah dan mengkonversi gambar text menjadi sebuah text [3]. Metode yang cukup populer yang digunakan dalam permasalahan pencocokan pola pada pengolahan citra digital [10].

Pada dasarnya Template Matching sederhana. Gambar input berisi templat dibandingkan dengan templat di database. Templat ditempatkan di tengah bagian gambar yang kemudian akan dibandingkan dan dikalulasi titik yang paling cocok untuk templat. Langkah kemudian akan dilakkan untuk seluruh gambar input yang akan dibandingkan. Nilai pencocokan titik terbesar antara gambar input dan gambar template menunjukkan bahwa template adalah gambar template yang paling cocok dengan gambar input.

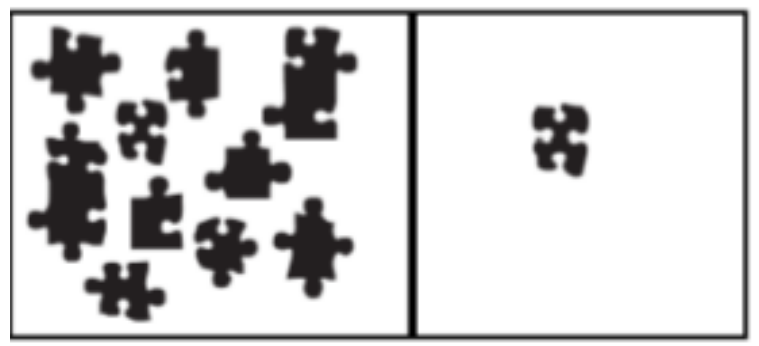

Gambar 7 Contoh Template Matching

Pada gambar 7 bagian kanan merupakan citra template, kemudian citra kiri merupakan citra yang mengandung object yang sama dengan template. Kemudian untuk citra yang akan dibandingkan persentase kesesuaiannya, template diposisikan pada pola pada citra masukan dengan pola pada citra template.

Kemudian template dengan nilai eror paling kecil adalah template yang paling sesuai dengan template atau citra masukan. Tambahan ruang penyimpanan diperlukan untuk ukuran citra yang beragam dimana diperlukan untuk menggunakan template dengan ukuran yang berbeda.

Misalkan jika suatu template berukuran persegi dengan ukuran $\mathrm{m} x \mathrm{~m}$ dan sesuai dengan citra yang berukuran $\mathrm{N} \times \mathrm{N}$, dengan pmisalan pixel $\mathrm{m} 2$ sesuai dengan semua titik. Komputasi yang dilakukan harus dengan template yang tidak beragam. Penambahan template dengan berbagai ukuran akan membutuhkan komputasi yang besar.

kemudian bagian yang merupakan region of interest dari tahap sebelumnya dipotong / disegmentasi menjadi potongan citra yang hanya memuat satu karakter pada setiap citra, 
persentase keberhasilan sistem pada tahap ini terletak pada keberhasilan sistem melakukan segmentasi terhadap setiap karakter yang terdapat pada citra plat [11]. Hasil segmentasi yang buruk akan menurunkan kemungkinan karakter untuk dikenali dengan tepat [12].

Proses pelabelan pada segmentasi apabila nilai koefisien array piksel sudah bernilai true, maka proses scanline akan dihentikan dan dilanjutkan pada baris berikutnya [13].

Komputasi juga akan bertambah jika parameter dari pada template bertambah, seperti beragamnya ukuran template. Hal ini yang menyebabkan metode template matching menjadi lamban.

Langkah pengenalan plat dilakukan melalui langkah sebagai berikut :

1. Gambar yang dicapture akan diambil gambar plat nya saja dengan menggunakan komputasi histogram.

2. Gambar hasil histogram akan menampilkan gambar hitam putih seperti berikut.

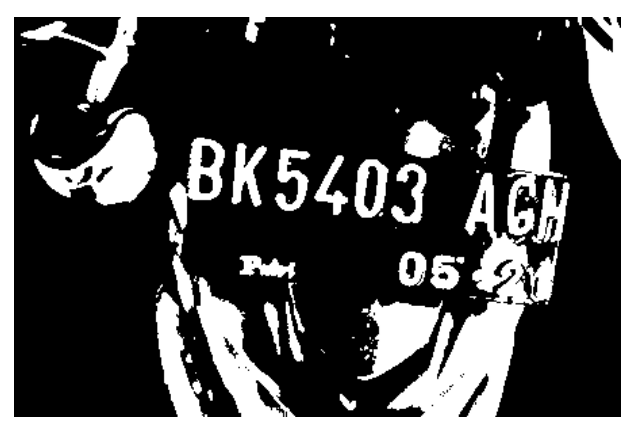

Gambar 8 Contoh Gambar hasil histogram

3. Kemudian gambar hasil komputasi histogram akan dilakukan cropping image dan proses negasi. Sehingga hasil gambar akan didapatkan sebagai berikut

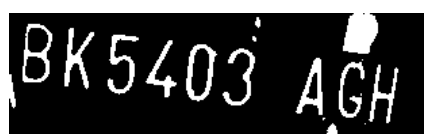

4. Gambar hasil histogram kemudian akan di segmentasi karakternya.

5. Kemudian gambar hasil segmentasi akan dicocokkan dengan dataset yang telah dilatih.

\section{HASIL DAN PEMBAHASAN}

Kemudian dilakukan percobaan pada 20 plat kendaraan, dimana hasil yang diperoleh setelah melakukan penelitian adalah sebagai berikut:

Tabel 2 Tabel hasil penelitian dengan 10 plat

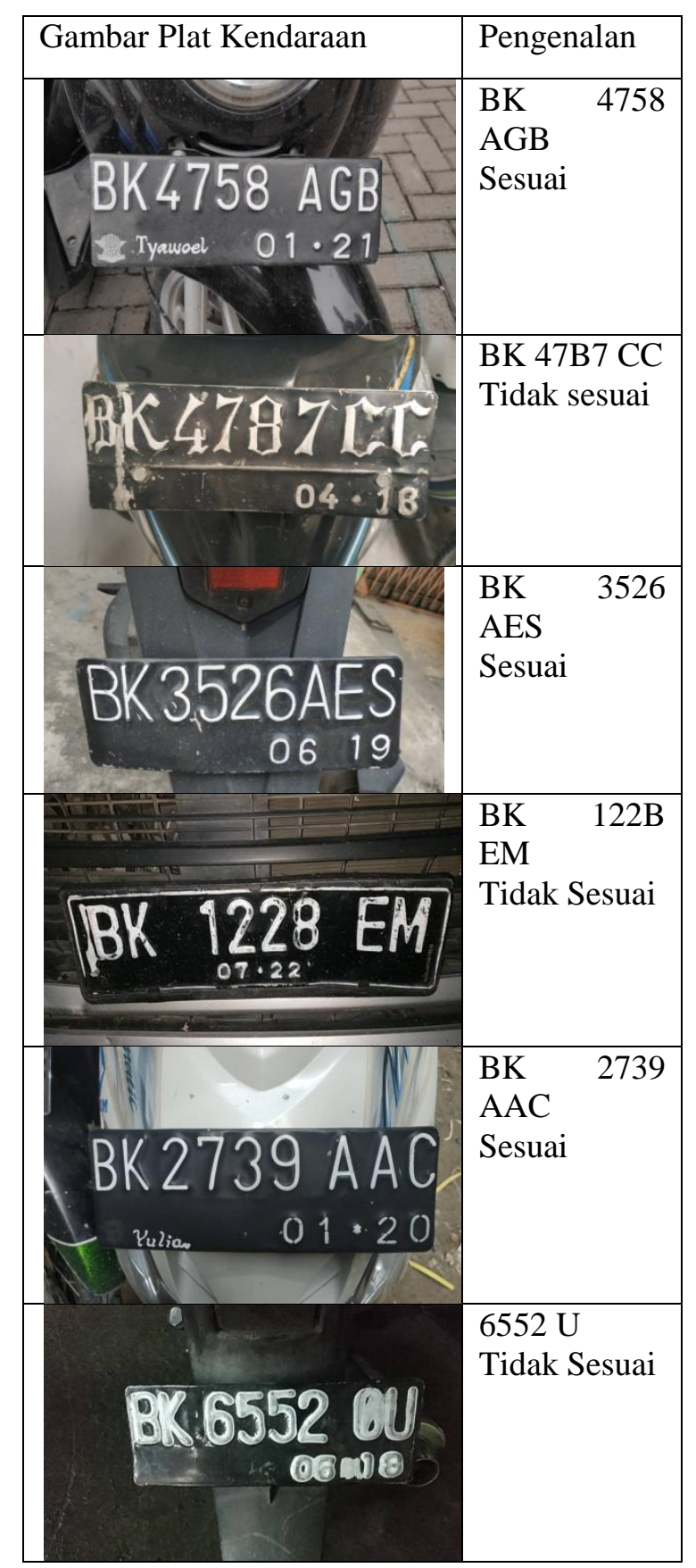




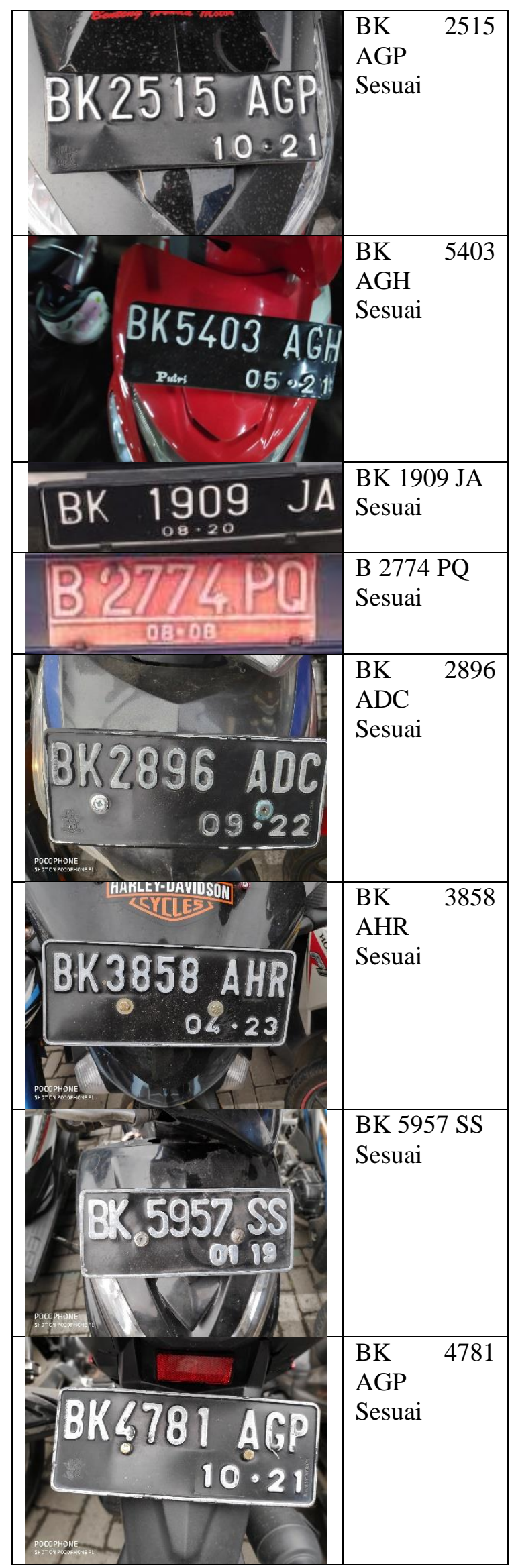

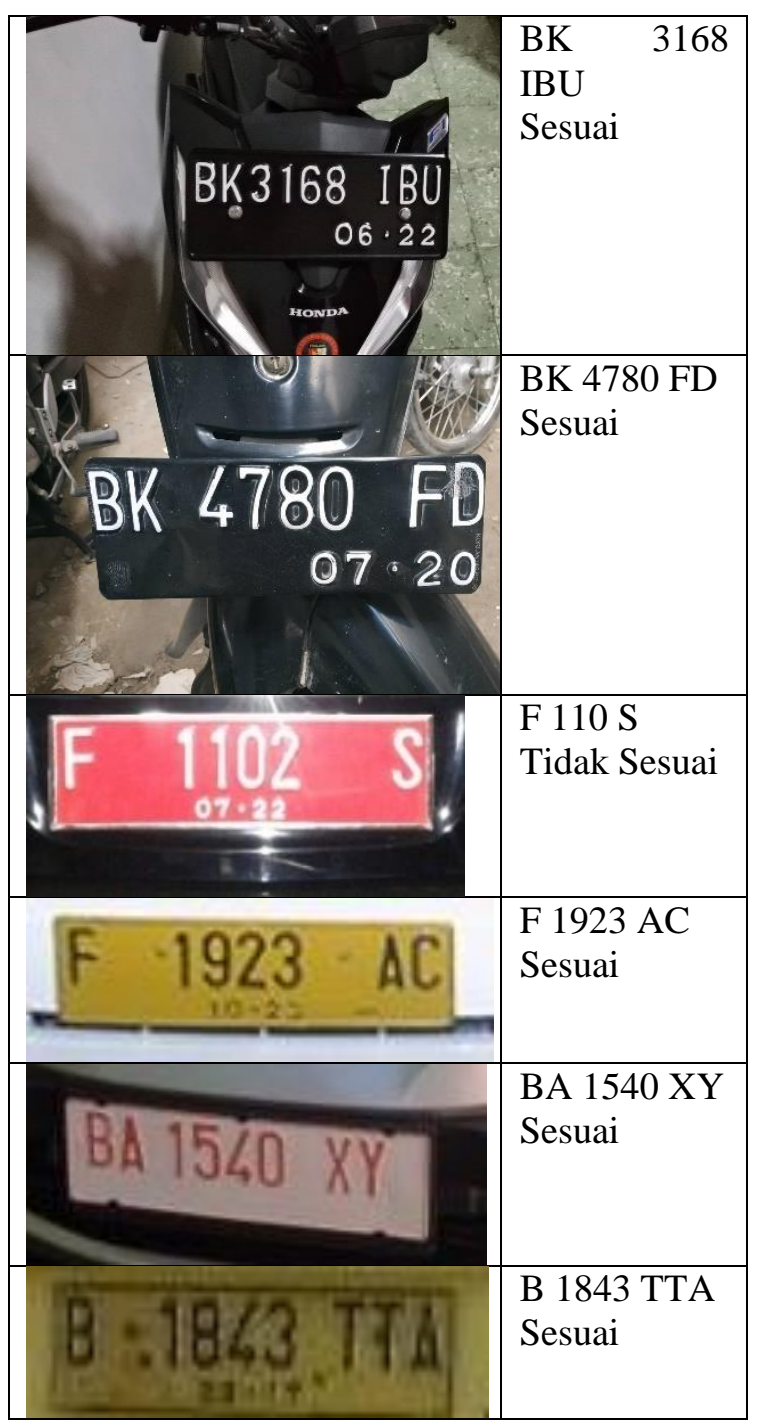

Dari percobaan pada 20 plat yang dilakukan diatas, 16 plat berhasil dikenali dan sesuai dengan plat yang dapat terbaca oleh manusia.

Dimana kegagalan yang terjadi pada beberapa plat umumnya terjadi karena gagalnya proses segmentasi dalam menghasilkan karakter yang dapat terbaca. Berikut adalah tabel yang menunjukkan hasil percobaan yang dilakukan. Untuk menghitung akurasi testing maka rumus yang akan digunakan adalah sebagai berikut:

$$
\frac{\text { Jumlah huruf dikenali }}{\text { Jumlah total huruf }} \times 100 \%
$$

\begin{tabular}{|l|l|c|}
\hline $\begin{array}{l}\text { Hasil } \\
\text { Segmentasi }\end{array}$ & $\begin{array}{l}\text { Dikenali } \\
\text { sebagai }\end{array}$ & Persentase \\
\hline BK4758AGB & BK4758AGB & $100 \%$ \\
\hline
\end{tabular}




\begin{tabular}{|c|c|c|}
\hline $\mathrm{BK} 4787 \mathrm{CC}$ & BK47B7CC & $87,5 \%$ \\
\hline BK3526AES & BK3526AES & $100 \%$ \\
\hline BK1228EM & BK122BEM & $87,5 \%$ \\
\hline BK2739AAC & BK2739AAC & $100 \%$ \\
\hline BC6552U & $6552 \mathrm{U}$ & $62,5 \%$ \\
\hline BK2515AGP & BK2515AGP & $100 \%$ \\
\hline BK5403AGH & BK5403AGH & $100 \%$ \\
\hline BK1909JA & BK1909JA & $100 \%$ \\
\hline B2774PQ & B2774PQ & $100 \%$ \\
\hline BK2896ADC & BK2896ADC & $100 \%$ \\
\hline BK3858AHR & BK3858AHR & $100 \%$ \\
\hline BK5957SS & BK5957SS & $100 \%$ \\
\hline BK4781AGP & BK4781AGP & $100 \%$ \\
\hline BK3168IBU & BK3168IBU & $100 \%$ \\
\hline BK4780FD & BK4780FD & $100 \%$ \\
\hline F1102S & F110S & $83.3 \%$ \\
\hline F1923AC & F1923AC & $100 \%$ \\
\hline BA1540XY & BA1540XY & $100 \%$ \\
\hline
\end{tabular}

\begin{tabular}{|l|l|l|}
\hline & & \\
\hline B1843TTA & B1843TTA & $100 \%$ \\
\hline
\end{tabular}

Grafik pada percobaan yang dilakukan tampak seperti pada gambar dibawah berikut :

\section{Grafik Hasil Percobaan}

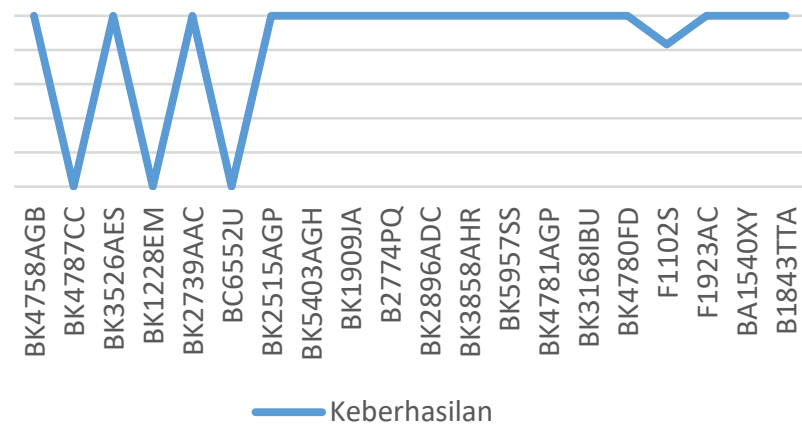

Pada keseluruhan percobaan pengenalan yang berhasil mengenali hingga $100 \%$ adalah sebanyak 16 plat sedangkan 4 plat lainnya gagal dikenali sehingga persentase keberhasilan pengenalan plat pada 20 percobaan yang diakukan adalah $80 \%$.

Dari percobaan diatas proses segmentasi yang gagal terjadi hanya pada percobaan dengan plat nomor BK6552OU dimana hasil segmentasi tidak dapat membaca huruf $\mathrm{O}$ dibelakang dan juga BK didepan. Hal ini dikarenakan kondisi plat yang juga kurang jelas, dimana gambar plat adalah sebagai berikut

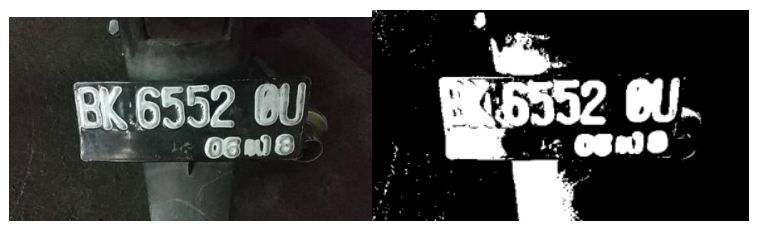

Pada gambar diatas dapat dilihat bahwa karena huruf $\mathrm{B}$ dan $\mathrm{K}$ yang terlalu dekat citra tidak dapat melakukan segmentasi dengan baik, selain itu huruf $O$ juga tidak dapat dikenali karena tidak berbentuk. Contoh lainnya yang sering terjadi kesalahan adalah pada pengenalan huruf $B$ dengan 8 dan 1 dengan I. Seperti pada pengenalan plat dibawah. 


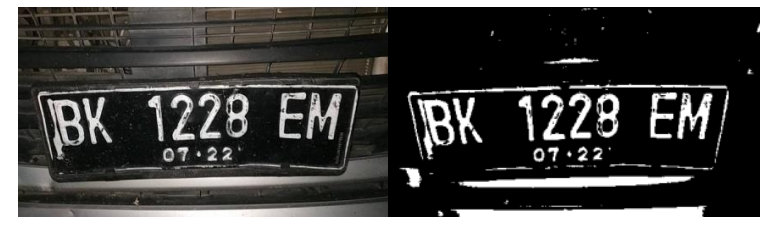

Pada gambar diatas karena pada angka 8 terdapat jejak hitam ,kemudian pada proses segmentasinya ketika dilakukan pencocokan pola dikenali sebagai B.

\section{SIMPULAN DAN SARAN}

Setelah melakukan analisa dan pembahasan pada pengenalan plat kendaraan dengan algoritma Deep Belief Network dan Template Matching dapat diambil kesimpulan seperti dibahwa ini:

1. Dari 20 percobaan keberhasilan algoritma Deep Belief Network mengenali plat secara utuh adalah sebanyak 15 kali, dan 5 kali gagal.

2. Algortima Deep Belief Network dan Template Matching dapat melakukan pengenalan plat kendaraan, namun jika plat kendaraan rusak atau kurang pencahayaan maka akan kurang akurat. Namun persentase keberhasilan dari 20 percobaan yang dilakukan adalah $80 \%$.

3. Penerapan algoritma Deep Belief Network untuk pengenalan plat kendaraan dapat diterapkan dengan langkah berikut, yaitu dengan melakukan pembelajaran data terlebih dahulu, kemudian setelah melakukan pembelajaran dataset. Ketika akan melakukan pengenalan, terlebih dahulu dilakukan algoritma template matching.

4. Setelah melakukan template matching, maka akan dilakukan pencarian karakter yang mirip dengan plat kendaraan.

Setelah melakukan penelitian penulis dapat member saran sebagai berikut:

1. Dapat diimplementasikan dengan alat lainnya seperti barrier gate atau vld, sehingga apabila plat yang terbaca sesuai, barrie gate dapat langsung terbuka.

2. Algoritma dapat dikembangkan dengan menggabungkan algoritma pengolahan gambar lainnya, sehingga gambar hasil ekstrasi dapat lebih sempurna.

\section{Ucapan Terima Kasih}

Kami ingin mengucapakan terima kasih yang sebanyak-banyaknya kepada Bapak Abdi
Dharma, S.Kom, M.Kom, sebagai Dosen Pembimbing yang telah memberikan banyak bimbingan, dorongan semangat dan kritik yang berguna untuk penelitian ini. Saya juga ingin berterima kasih kepada Jurnal Matrik yang telah membantu kami menjadi Peer-Reviewers dalam penerbitan Volume 19 No 12019.

Dan yang terakhir, kami ingin mengucapkan terima kasih kepada orang tua kami atas dukungan dan dorongan mereka selama masa belajar kami

\section{REFERENSI}

[1] Z. Bahri and J. Risanto, "Sistem Pengenalan Nomor Plat Kendaraan Berbasis Foto Dijital Dengan Metode Moment Invariant dan Jaringan Syaraf Tiruan Menggunakan Algoritma Backpropagation," Pros. Semirata FMIPA Univ. Lampung, 2013, no. 1, pp. 571-581, 2013.

[2] Z. Rahman, “Aplikasi Identifikasi Nomor Kendaraan Berbasis Android Dengan Metode Learning Vector Quantization," Tek. Inform., no. May, 2015.

[3] A. Bondarenko and A. Borisov, "Research on the Classification Ability of Deep Belief Networks on Small and Medium Datasets," Inf. Technol. Manag. Sci., vol. 16, no. 1, 2014.

[4] M.Maskuri, "Implementasi Metode Template Matching Untuk Media Pembelajaran Pengenalan Karakter Huruf Alphabet," vol. 01, no. 11, 2017.

[5] A. Meilandanu, "Pengenalan Plat Nomor Kendaraan Bermotor Menggunakan Metode Diagonal Distance Feature". Fakultas Teknologi dan Informatika.Institut Bisnis dan Informatika STIKOM Surabaya, 2017.

[6] Liliana, G. S. Budhi, and Hendra, "Segmentasi Plat Nomor Kendaraan Dengan Menggunakan Metode RunLength Smearing Algorithm (RLSA)," no. March 2016, 2010.

[7] S. Hartanto, A. Sugiharto, and S. N. Endah, "Optical Character Recognition Menggunakan Algoritma Template Matching Correlation," J. Masy. Inform., vol. 5, no. 9, pp. 1-12, 2015. 
[8] Giali Ghazali, Jondri. "Prediksi Saham Menggunakan Dbn ( Deep Belief Network )". Ilmu Komputasi Fakultas Informatika Universitas Telkom, Bandung, 2017.

[9] D. Avianto, "Pengenalan Pola Karakter Plat Nomor Kendaraan Menggunakan Algoritma Momentum Backpropagation Neural Network," J. Inform., vol. 10, no. 1, pp. 1199-1209, 2016.

[10] Tari Mardiana, R. D. Nyoto, and H. Nasution, "Pengenalan Plat Nomor Kendaraan Menggunakan Metode Connected Component Labeling dan KNearest Neighbor'.," pp. 1-8.

[11] J. Supardi, D. Rodiah, J. Teknik, and I. Universitas, "Pengenalan plat kendaraan bermotor dengan teknik he guanglin dan guo yali 1,2)," J. Res. Comput. Sci. Appl. 01 (01). ISSN 2301-8488, pp. 1-7, 2015.

[12] O. Mellolo, "Pengenalan Plat Nomor Polisi Kendaraan Bermotor," J. Ilm. Sains, vol. 12, no. 1, p. 35, 2012.
[13] Y. Rizk, N. Hajj, N. Mitri, and M. Awad, "Deep belief networks and cortical algorithms: A comparative study for supervised classification," Appl. Comput. Informatics, vol. 15, no. 2, pp. 81-93, 2019.

[14] David, "Pengenalan Pola Plat Nomor Kendaraan Menggunakan Jaringan Syaraf Tiruan Backpropagation," J. Ilm. SISFOTENIKA, vol. 3, no. 1, pp. 71-80, 2006.

[15] Ira Zulfa, Edi Winarko. "Sentimen Analisis Tweet Berbahasa Indonesia dengan Deep Belief Network". FMIPA UGM, Yogyakarta , Indonesia. Departemen Ilmu Komputer dan Elektronika, FMIPA UGM, Yogyakarta Indonesia, 2017. 